\title{
無重力場における常磁性空気の磁気熱対流の数値計算*1 Numerical Computations of Magnetothermal Convection of Paramagnetic Air in a Non-Gravitational Field
}

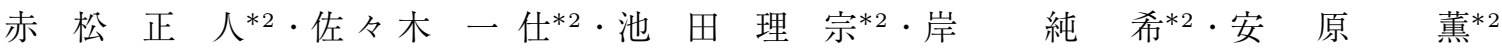 \\ Masato Akamatsu, Kazushi Sasaki, Masamune Ikeda, Junki Kishi and Kaoru Yasuhara
}

Key Words : Heat Transfer, Heat Conduction, Simulation, Magnetic Force, Air

\begin{abstract}
Convective heat transfer characteristics of paramagnetic air induced by magnetic force in a nongravitational field are scrutinized by two-dimensional numerical computations. In the present research, a shallow cylindrical enclosure filled by paramagnetic air is assumed to be placed inside the bore space of a superconducting magnet. Our numerical results find out that the strength of magnetothermal convection induced by magnetic force in quiescent air under thermal conduction state strongly depends on the relative positions of the enclosure and magnetic center, and the oscillatory magnetothermal convection with regular period and amplitude is generated when the enclosure is placed near the magnetic center. These phenomena can be successfully explained by considering the magnetic susceptibility of paramagnetic substance according to Curie's law. In addition, effect of the magnetic force in a gravitational field is also evaluated by examining magnetothermal convection induced by magnetic force in density stratified air.
\end{abstract}

\section{記号の説明}

$a:$ 円形電磁コイルの半径 $(\mathrm{m})$

$\boldsymbol{a}:$ 円形電磁コイルの位置ベクトル $=(a, z)(\mathrm{m})$

$\boldsymbol{A}:$ 円形電磁コイルの位置ベクトル $=\boldsymbol{a} / h$

$\boldsymbol{b}:$ 磁束密度 $(\mathrm{T})$

$b_{0}:$ 参照磁束密度 $=\xi i / h(\mathrm{~T})$

$\boldsymbol{B}:$ 無次元磁束密度 $=\boldsymbol{b} / b_{0}$

$f:$ 磁気力 $\left(\mathrm{N} / \mathrm{m}^{3}\right)$

$g:$ 重力加速度 $\left(\mathrm{m}^{2} / \mathrm{s}\right)$

$h:$ 冷却面と加熱面の距離 $(\mathrm{m})$

$i$ : 円形電磁コイルに流れる電流 $(\mathrm{A})$

$H R$ : 円筒容器半径 $=5 H Z$

$H Z$ : 冷却面と加熱面の距離 $=h / h$

$N u$ : ヌセルト数

$p:$ 圧力 $(\mathrm{Pa})$

$p_{0}:$ 参照圧力 $=\left(\rho \alpha^{2}\right) / h^{2}(\mathrm{~Pa})$

$P:$ 無次元圧力 $=p / p_{0}$

$\operatorname{Pr}:$ プラントル数

$Q:$ 伝熱量

$r:$ 半径方向座標 $(\mathrm{m})$

$\boldsymbol{r}:$ 容器内の位置ベクトル $=(r, z)(\mathrm{m})$

$R:$ 無次元半径方向座標 $=r / h$

$\boldsymbol{R}:$ 容器内の位置ベクトル $=\boldsymbol{r} / h$

$R a:$ レイリー数

$t:$ 時間 $(\mathrm{s})$

\footnotetext{
*1 (C) 2012 日本航空宇宙学会

平成 23 年 9 月 13 日原稿受付

*2 山形大学大学院理工学研究科
}

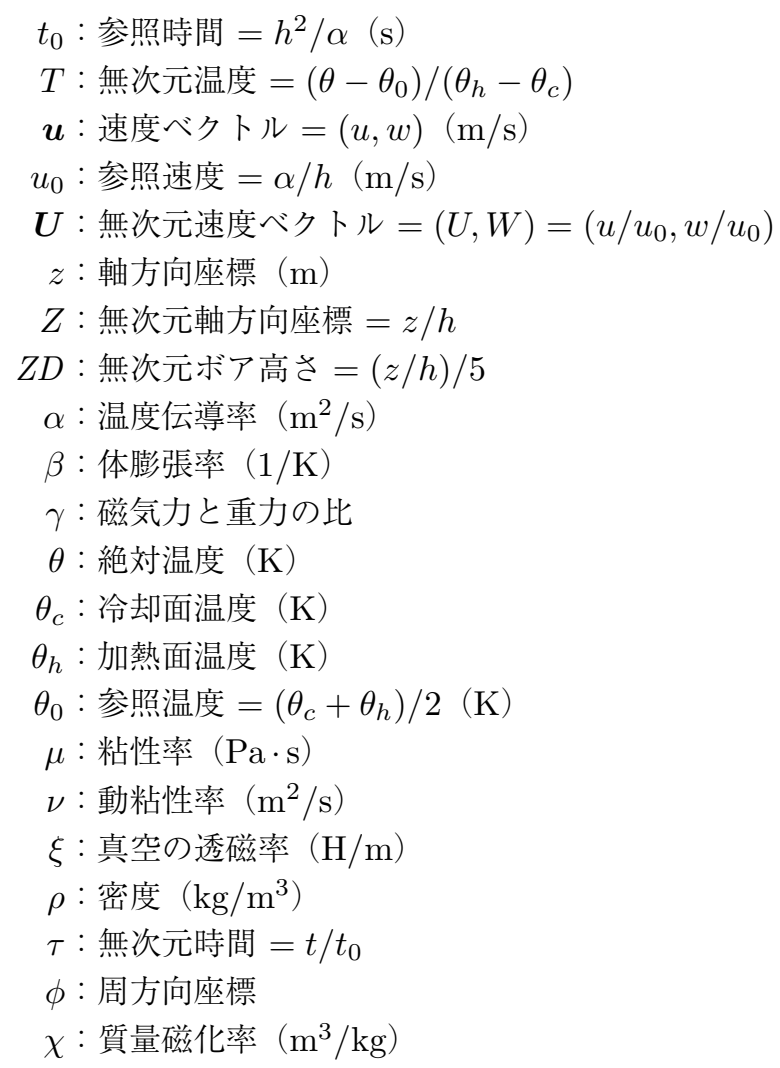

1.はじめに

これまで, 熱対流を磁気力により制御しようとする研究 は主に電気伝導性流体 ${ }^{1,2)}$ や磁性流体 3,4$)$ を対象に行われて きた，しかし，最近の超伝導磁石の性能改善により 10 [T] 程度の強磁場が比較的容易に利用できるようになり, 水や 空気といった非磁性流体の熱対流制御に磁気力を利用しよ 
うとする研究が盛んに行われるようになった。なお，非磁性 熱流体の磁気力制御に関する研究に火をつけたのは, 1991 年, Nature 誌に揭載された Braithwaiteらの研究5) である と考えられる. その後, 多くの研究者によって磁気力に関 する研究がなされ，工学的にも興味深い様々な新現象が発 見されている。例えば，若山グループは勾配磁場下におけ る反磁性窒素ガスの挙動を実験と数值解析の両面から調べ, 窒素ガスが磁気力によりジェット気流のように加速される ことを発見 ${ }^{6)}$ した。他にも，微小重力下において磁気力を 利用した拡散燃焼炎の持続に成功》するなど，磁気力を利 用した様々な研究を精力的に行っている8,9). また, 北澤グ ループも同種の研究に注力し, 常磁性と反磁性液体の磁気 浮上 ${ }^{10)}$ や, 機械的駆動力無しに磁気力だけで熱風を発生 ${ }^{11)}$ させるなど，今後，実用プロセスへの応用が期待される多 くの成果を上げている，著者らの 1 人は北澤グループが発 見した磁気熱風11)の工学的利用を模索するため, その伝熱 流動特性を数值解析的に解明した ${ }^{12,13)}$.

本研究では, 磁気力によって誘起された非磁性磁気熱対 流の伝熱流動特性を体系的にまとめるための研究14,15) の一 環として，また磁気力の宇宙利用を模索するための基礎的 研究として, 無重力場に扔ける薄い加熱密閉円筒容器内に 封入された常磁性空気に対する磁気力の効果を数值解析に よって詳細に調べたので報告する。

\section{2. 解 析モデル}

第 1 図は, 本研究グループ所有の住友重機械工業株式 会社製の超伝導マグネット（HF5-100VHT）である。小 型冷凍機で直接超伝導コイルを冷却するため, 液体へリ ウムを全く必要としない16)。本体は外径, 高さともに約 $0.5[\mathrm{~m}]$ で, 中心にボア直径 $0.1[\mathrm{~m}]$ （鉛直方向に貫通）の 室温空間を持つ.この空間に扔いて, 最大 $5[\mathrm{~T}]$ の磁束密 度で $b_{z} \cdot \mathrm{d} b_{z} / \mathrm{d} z=150\left[\mathrm{~T}^{2} / \mathrm{m}\right]$ の磁気勾配を発生すること ができる。この磁気勾配の下では常磁性の空気に対して重 力の約 4 倍の磁気力を, 一方, 反磁性の水に対して重力の 約 0.1 倍の磁気力を作用させることができる. なお，本体 は $360^{\circ}$ 回転可能なので室温ボア方向を垂直・水平など任 意の方向に設置できる.

第 2 図は，本数值計算で想定した解析モデルである。こ れは，無重力場に抏いて第 1 図に示した超伝導マグネット のボア内に，常磁性空気で満たされた加熱密閉円筒容器が 設置されていることを想定している. 容器のアスペクト比 は 10 (= 直径/高さ), 端面は一定温度で泠却 $\left(\theta_{c}\right)$ され, もう一方の端面は一定温度で加熱 $\left(\theta_{h}\right)$ されている. 容器 側面は断熱されている。ボア内で発生する非一様な磁場は, 1 巻の円形電磁コイルに定常電流が流れることで発生する 静磁場で模擬した。この電磁コイルは容器と同軸に設置さ れており,コイルの半径は容器のそれの 2 倍とした.

\section{3. 無次元基礎方程式}

第 1 図に示した超伝導磁石が市販されるようになり，5〜 $10[\mathrm{~T}]$ 程度の強磁場が以前より比較的容易に利用できるよ

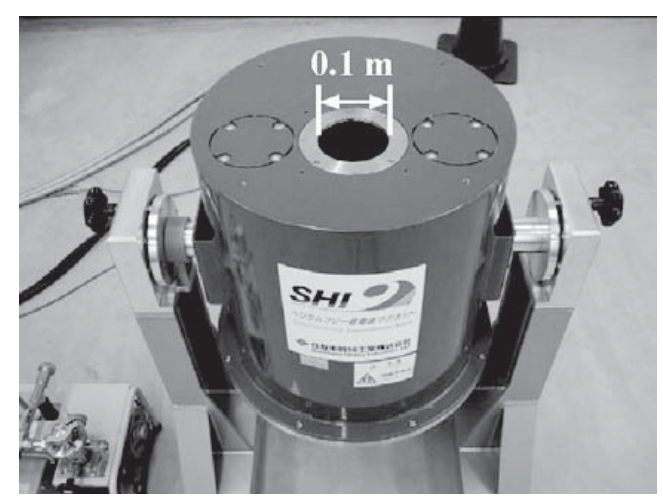

第1図 ヘリウムフリー超伝導マグネット

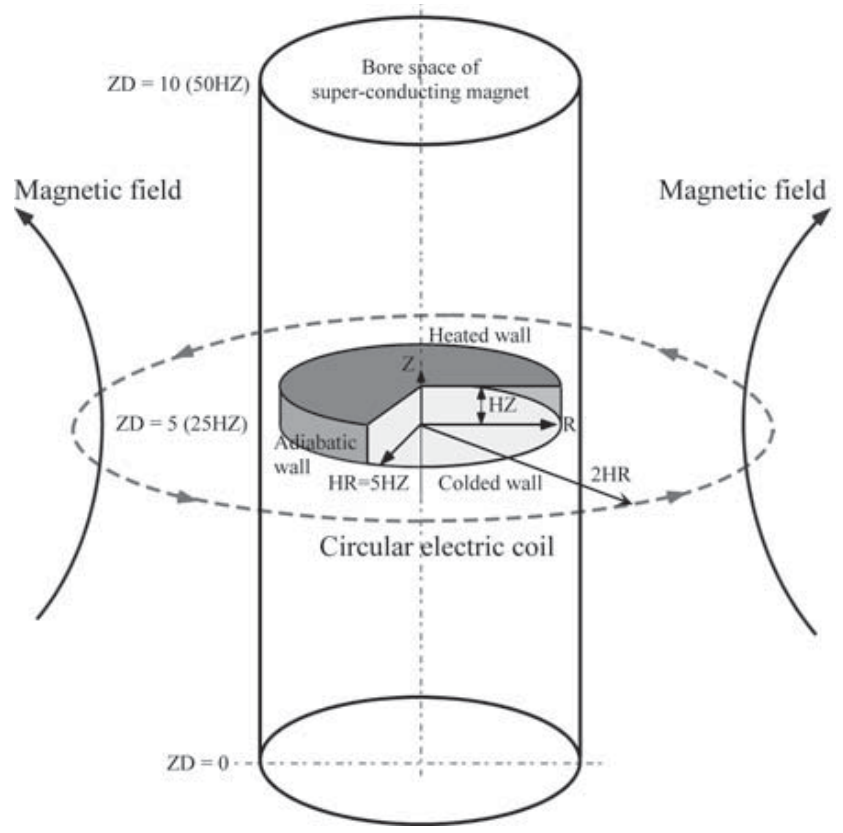

第 2 図 解析モデル

うになった。このため, 従来無視されてきた磁気力が無視 できない大きさになった，磁場勾配下で発生する磁気力6) を式 (1) に示す.

$$
\vec{f}=\frac{\rho \chi}{2 \xi} \nabla b^{2}
$$

磁気力は, 磁束密度の 2 乗の勾配に比例する。すなわち, 一様磁場下ではこの力は発生しない, また, 磁気力の単位 $\mathrm{N} / \mathrm{m}^{3}$ と重力 $\rho g$ のそれは同一であり, ともに体積力である.

式 (2) は, 式 (1) に示した磁気力が外力として付加され た重力場における運動方程式である。

$$
\rho \frac{\mathrm{D} \vec{u}}{\mathrm{D} t}=-\nabla p+\mu \nabla^{2} \vec{u}+\frac{\rho \chi}{2 \xi} \nabla b^{2}+\rho \vec{g}
$$

ここで, 常磁性体の磁化率 $\chi$ は式 (3) に示すようにCurie の法則に従う。つまり, 磁化率は絶対温度 $\theta$ に反比例する.

$$
\chi \propto \frac{1}{\theta}
$$

そこで, 式 (3) の磁化率の温度依存性を考慮し, さらに, 自然対流の数值計算で用いられる変動圧力の導入抢よび 
Boussinesq 近似を用いると, 式 (2) は式 (4)のように書き 換えることができる17).

$$
\begin{aligned}
\frac{\mathrm{D} \vec{u}}{\mathrm{D} t}= & -\frac{1}{\rho_{0}} \nabla p^{\prime}+\frac{\mu}{\rho_{0}} \nabla^{2} \vec{u}-\frac{\chi \beta}{\xi}\left(\theta-\theta_{0}\right) \nabla b^{2} \\
& +g \beta\left(\theta-\theta_{0}\right) \nabla z
\end{aligned}
$$

以下は, 無次元化された基礎方程式である. 式 (5) は連 続の式, 式 (6) は重力場における磁気力項を含む運動方程 式，そして式(7) はエネルギー方程式である。

$$
\begin{aligned}
\nabla \cdot \vec{U}= & 0 \\
\frac{\mathrm{D} \vec{U}}{\mathrm{D} \tau}= & -\nabla P+\operatorname{Pr} \nabla^{2} \vec{U}-\gamma \operatorname{RaPr} T \nabla B^{2} \\
& +\operatorname{RaPrT} \nabla Z \\
\frac{\mathrm{D} T}{\mathrm{D} \tau}= & \nabla^{2} T
\end{aligned}
$$

また，第 2 図に示した 1 巻の円形電磁コイルから発生す る非一様な磁束密度分布は, 式 (8) に示す Biot-Savart の 法則から計算した。

$$
\vec{B}=-\frac{1}{4 \pi} \oint \frac{(\vec{A}-\vec{R}) \times \mathrm{d} \vec{A}}{|\vec{A}-\vec{R}|^{3}}
$$

式 (6)は重力場に扔ける運動方程式である。このとき, 現 象を支配する無次元パラメー夕は以下に示す $\gamma, R a$ 数, そ して $P r$ 数である.なお, $\gamma$ は磁気力と重力の比を表す新 しい無次元数である.

$$
\gamma=\frac{\chi b_{0}^{2}}{\xi g h}, \quad R a=\frac{g \beta\left(\theta_{h}-\theta_{c}\right) h^{3}}{a v}, \quad \operatorname{Pr}=\frac{v}{a}
$$

本研究で着目している無重力場における計算では, 式 (6) の右辺第 4 項の浮力項を削除して計算した，このとき，現 象を支配する無次元パラメー夕は $\gamma \cdot R a$ と $\operatorname{Pr}$ 数である.

円筒容器端面，すなわち冷却面と加熱面に扔ける平均 $N u$ 数は式 (10) から求めた. $Q_{\text {cond }}$ は伝導伝熱量, $Q_{\text {conv }}$ は対 流伝熱量である。

$$
N u_{\text {ave }}=\frac{Q_{\text {conv }}}{Q_{\text {cond }}}=\frac{\int_{0}^{2 \pi} \int_{0}^{H R}\left(\frac{\partial T_{\text {conv }}}{\partial Z}\right) \cdot R \cdot \mathrm{d} R \cdot \mathrm{d} \phi}{\int_{0}^{2 \pi} \int_{0}^{H R}\left(\frac{\partial T_{\text {cond }}}{\partial Z}\right) \cdot R \cdot \mathrm{d} R \cdot \mathrm{d} \phi}
$$

\section{4. 数值計算法}

本数值計算は, 有限差分法によって近似した，時間差分 には陽解法を，そして圧力の解法にはHSMAC 法をそれぞ れ用いた。 なお，対流項は UTOPIA スキームと呼ばれる 3 次精度の風上差分, 一方, 拡散項は 4 次精度の中心差分で 離散化した ${ }^{18)}$. 収束判定に関しては， $\nabla \cdot \boldsymbol{U} \leq 10^{-5}$ を満 足するまで, 圧力の反復計算を行った。計算格子は, スカ ラーの定義点と速度の定義点を半格子ずらして定義するス
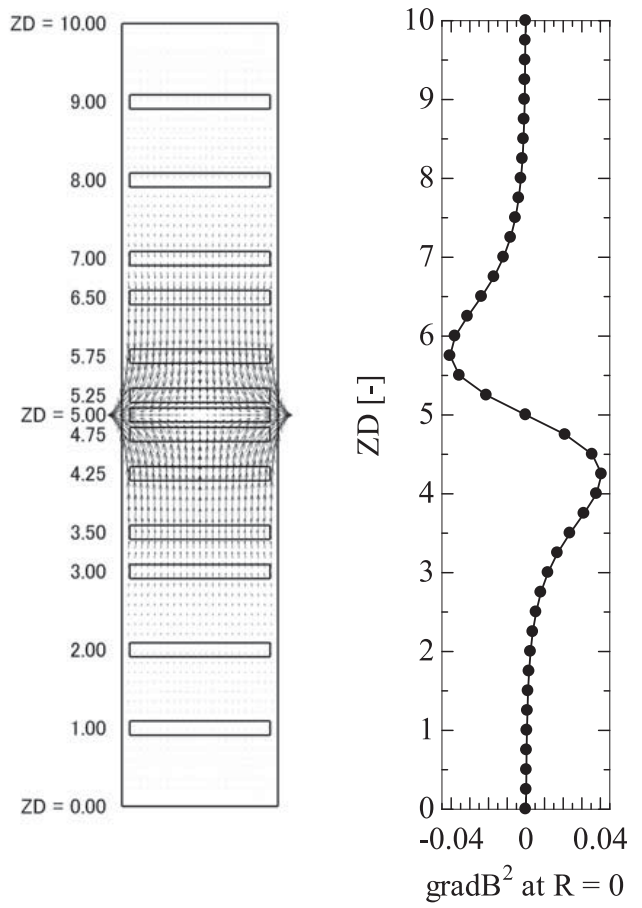

第 3 図 ボア内の磁束密度の 2 乗の勾配ベクトルと容器設置位置そし てボアの中心軸上における $\left(\operatorname{gradB}^{2}\right)_{Z}$

タッガード格子を用いた，格子間隔は不等間隔である．第 3 図の左図は, 式 (8) に示したBiot-Savart の法則から計算 されたボア内の磁束密度の 2 乗の勾配と容器設置位置（図 中の長方形) である。なお， $\nabla \cdot \boldsymbol{B}$ はほぼゼロである。

容器はボア内の異なる 13 カ所に設置して, 容器内に密 閉された常磁性空気に対する磁気力の効果を調べた. 右図 はボアの中心軸上に扔ける磁束密度の 2 乗の勾配の $Z$ 成 分 $\left(\operatorname{gradB} B^{2}\right)_{Z}$ である. $Z D=4.25$ で最大值, $Z D=5$ で ゼロ，そして $Z D=5.75$ で最小值をとる。初期条件は速 度と温度ともにゼロである。速度の境界条件は中心軸にお いて二次元軸対称, そして容器端面と側面で滑りなしとし た. 一方, 温度の境界条件は容器中心軸において二次元軸 対称, 容器側面に扔いて断熱, そして容器端面において一 定温度の冷却面㧍よび加熱面とした。

\section{5. 数値計算結果}

第 4 図は，無重力場において磁気力によって誘起された常 磁性空気の磁気熱対流の速度べクトルと等温線である. 図 の右側が容器の中心, 左側が容器側壁, そして上端が加熱 面, 下端が冷却面である。ボア内に扔ける容器の設置位置 は $Z D=3,4.25,5,5.75,7$ であり, 第 3 図の左図でこれら の設置位置を確認することができる。例えば, $Z D=4.25$ に容器を設置したとき容器中心軸上の中点で $\left(\mathrm{gradB}^{2}\right)_{Z}$ が 最大值をとる。計算条件は, $\gamma \cdot R a=5 \times 10^{6}, P r=0.71$ である。異なる 5 つの容器設置位置において定常解が得ら れ，第 4 図はすべて定常状態に扔けるそれらである。磁気 力の効果が全くない場合, 等温線は伝熱面に対し平行とな るがすべての図に扔いて程度の差こそあれ等温線は曲がっ 
(a)

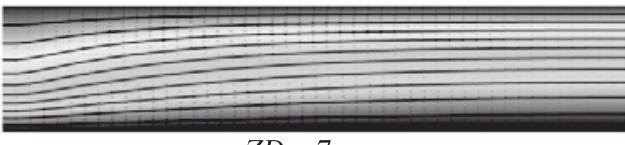

$Z D=7$

(b)

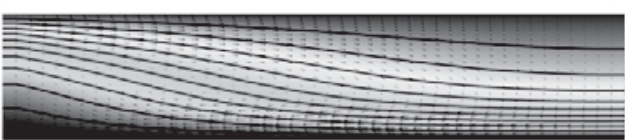

$Z D=5.75$

(c)

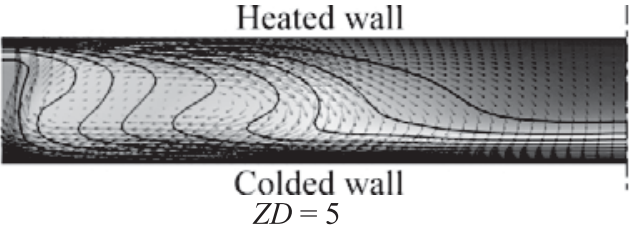

(d)

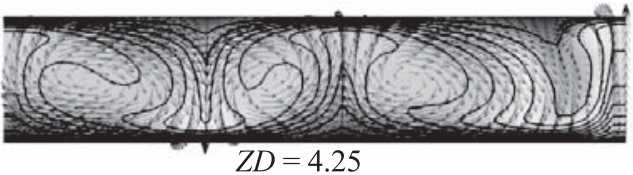

(e)

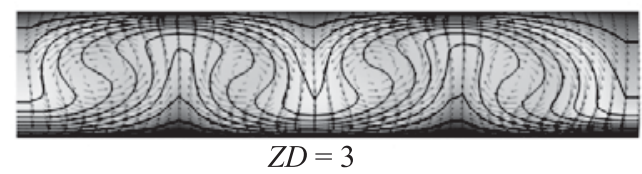

第4図無重力場において磁気力によって誘起された常磁性空気の磁気 熱対流の速度ベクトルと等温線（計算条件 : $\gamma \cdot R a=5 \times 10^{6}$, $\operatorname{Pr}=0.71)$

ており，磁気力によって磁気熱対流が誘起されたことを示 している。具体的には， $Z D=5$ 以下に容器を設置した場 合, 磁気力によって強い磁気熱対流が誘起されることがわ かった，特に， $Z D=4.25$ に容器を設置したとき最も強い 磁気熱対流が誘起された。一方, $Z D>5$ に容器を設置した 場合，ほとんど磁気熱対流が誘起されないことがわかった。

円形電磁コイルの設置位置, $Z D=5$ を境に磁気力によっ て誘起される磁気熱対流の様相が変化するのは以下の理由 からであると考えられる。本数值計算における対象流体は 常磁性である。常磁性はプラスの磁化率を持ち, 磁場に引 き付けられる性質を持つ。しかし, 式 (3) に示すように常 磁性の磁化率は絶対温度に反比例するので, 低温流体の磁 化率は高温流体のそれよりも大きくなる。このため, 本研 究で想定したモデルのように常磁性流体が密閉容器に封入 されている場合, 低温流体に対して磁気力は相対的に引力 として作用し, 一方, 高温流体に対して磁気力は相対的に 斥力として作用する。言い換えると, 低温流体は磁場のよ り強い方へ, 高温流体は磁場のより弱い方へ流動する. 本 数值計算では, 磁場の中心が $Z D=5$ にあるので, $Z D \leqq 5$ に容器を設置すると $Z D>5$ に容器を設置した場合よりも 強い磁気熱対流が磁気力によって誘起されると考えられる. 以上のことから, 無重力場における磁化率の温度依存性は 重力場における密度のそれに相当すると考えられる。

第 5 図は，重力場において磁気力によって誘起された常 磁性空気の磁気熱対流の速度べクトルと等温線である. 計

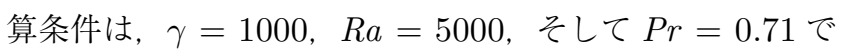

(a)

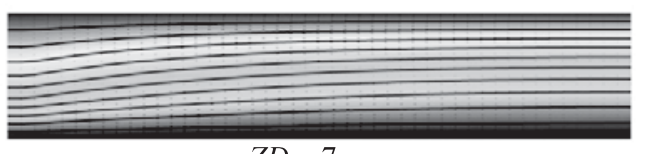

$Z D=7$

(b)

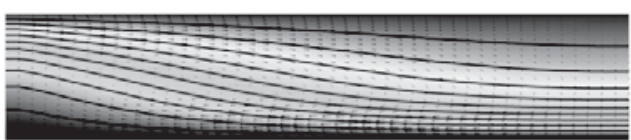

$Z D=5.75$

(c)

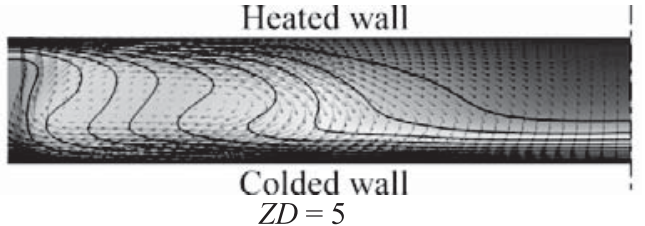

(d)

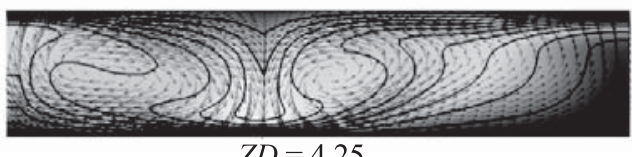

$Z D=4.25$

(e)

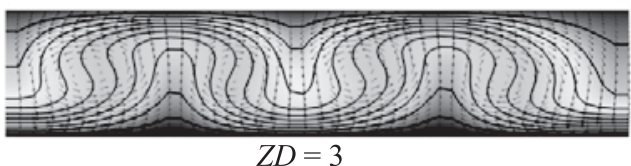

第 5 図 重力場において磁気力によって誘起された常磁性空気の磁気 熱対流の速度ベクトルと等温線（計算条件： $\gamma=1000, R a$ $=5000, \operatorname{Pr}=0.71$ )

ある。異なる 5 つの容器設置位置において定常解が得られ， 第 5 図はすべて定常状態におけるそれらである。重力場で は, 容器の底面を冷却, 一方, 容器の上面を加熱すると流 れの無い安定な密度成層空気が形成される。しかしながら, 第 5 図より磁気力が重力に打ち勝って, 程度の差こそあれ すべての容器設置位置において磁気熱対流が誘起されてい ることがわかる。しかし, 磁気力により誘起された流れは, 高温流体が下降し, 低温流体が上昇する, 重力場では考え られない流れである。これら重力場の磁気熱対流を第 4 図 の無重力場のそれらと比較すると, $Z D=4.25$ 以外の容 器設置位置において磁気熱対流の対流パターンはほぼ同様 であった，無重力場及び重力場ともに， $Z D=4.25$ に容 器を設置したとき, 最も強い磁気熱対流が誘起された。第 4 図 (d) と第 5 図 (d) より, 無重力場の方が冷却面から加 熱面に向かう低温流体, そして加熱面から冷却面に向かう 高温流体の流れが強い. 結果, 第 4 図 (d) の無重力場にお ける平均 $N u$ 数は 4.144 であったが, 第 5 図 (d) の重力場 における平均 $N u$ 数は 3.547 であり, 無重力場のそれの約 0.86 倍であった。この平均 $N u$ 数の減少は磁気力の効果が 重力により抑制されたことを示す。ここで, 円筒容器高さ を $0.009[\mathrm{~m}]$ と仮定すると, 容器直径は $0.09[\mathrm{~m}]$, また, 常 圧, $300[\mathrm{~K}]$ における空気の熱物性值 ${ }^{19)}$ を用いて有次元化 すると $\gamma=1000$ のときボアの中心軸上における最大磁束 密度は約 4.7 [T], また $R a=5000$ のとき伝熱面の温度差 は約 $73[\mathrm{~K}]$ になる。

第 6 図は, 第 3 図左図に示した容器設置位置における 

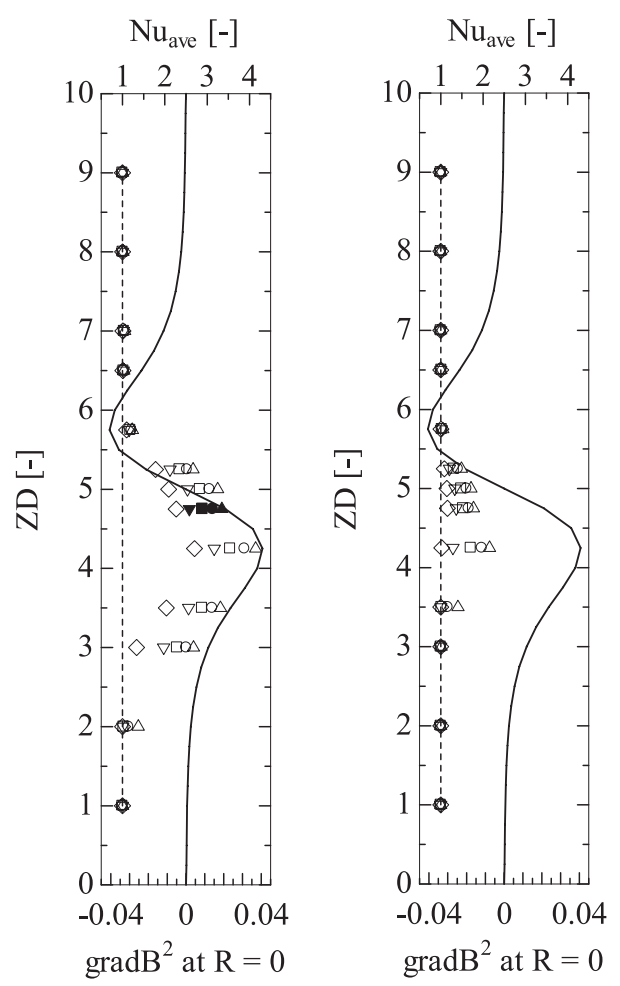

第 6 図 第 3 図左図に示した容器設置位置における伝熱面上の平均 $N u$ 数とボアの中心軸上における $\left(\operatorname{gradB}^{2}\right)_{Z}$

伝熱面上の平均 $N u$ 数 $(\triangle, \bigcirc, \square, \nabla, \diamond)$ とボアの中 心軸上における $\left(\mathrm{gradB}^{2}\right)_{Z}$ (実線) である。左図中の $\triangle$ は $\gamma \cdot R a=5 \times 10^{6}$, ○は $\gamma \cdot R a=4 \times 10^{6}, \square$ $\gamma \cdot R a=$ $3 \times 10^{6}, \nabla$ $\nabla \cdot R a=2 \times 10^{6}$, そして〉は $\gamma \cdot R a=$ $1 \times 10^{6}$ のときの平均 $N u$ 数である. 一方, 右図中の $\triangle$ は $\gamma \cdot R a=5 \times 10^{5}$, ○ $\gamma \cdot R a=4 \times 10^{5}, \square$,$\quad R \cdot R a=$ $3 \times 10^{5}, \nabla$ $\nabla \cdot R a=2 \times 10^{5}$, そして〉は $\gamma \cdot R a=$ $1 \times 10^{5}$ のときのそれである。 $P r$ 数は，すべての計算条件 において 0.71 である。なお, 左図の $Z D=4.75$ に容器を 設置した場合, $\gamma \cdot R a=1 \times 10^{6}$ 以外の 4 つの計算条件に おいて規則的振動磁気熱対流が発生したのでそれらは黒塗 りの記号で表示した。ここで, 平均 $N u$ 数は式 (10)より伝 熱面上における対流が生じているときの温度勾配と対流が 生じていないときの温度勾配との比を示す。言い換えると， 熱伝導と比較して熱伝達によりどれくらい多くの熱量が対 流の発生によって移動したかを示す。それ故, 平均 $N u$ 数が 1のとき, 系内は熱伝導場であり対流が発生していないこと を示す. 以上のことから, 加熱面における平均 $N u$ 数は熱 伝達により系に流入した熱量と熱伝導により系に流入した 熱量との比を示し, 一方, 冷却面における平均 $N u$ 数は熱 伝達により系から流出した熱量と熱伝導により系から流出 した熱量との比を示す。従って, 容器側壁が断熱条件であ るとき, 熱の出入は容器端面でのみ行われ, 加熱面と冷却 面の平均 $N u$ 数の比が 1 であるときは, 伝熱面を通して系 内に流出入する熱量が等しく, 熱バランスが保たれている と言える. 本数值計算におけるすべての計算条件において, 加熱面と冷却面の平均 $N u$ 数の比は $0.983 \leq N u_{\text {cold }} / N u_{\text {hot }}$ (a)

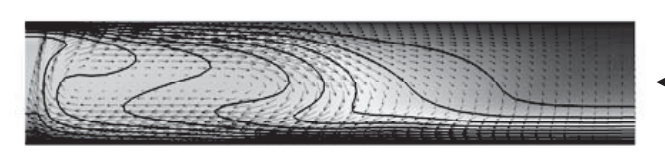

(b) $\downarrow$

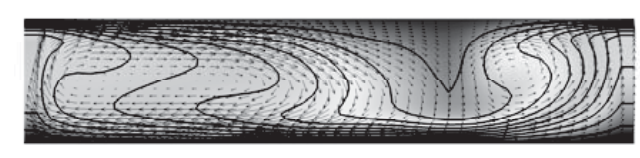

(c)

$\downarrow$

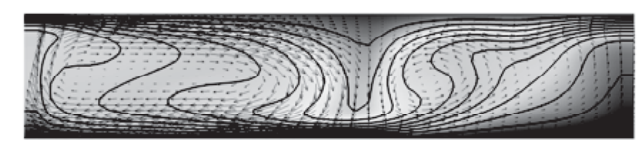

(d)

$\downarrow$

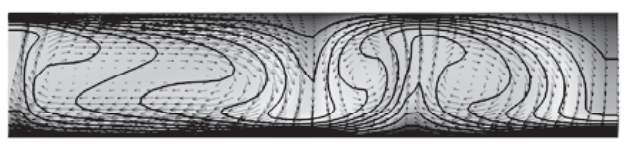

(e)

$\downarrow$

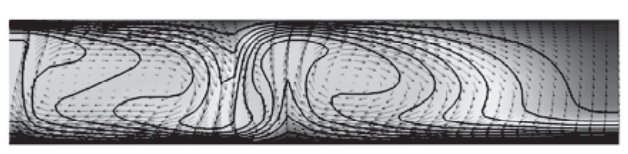

(f) $\downarrow$

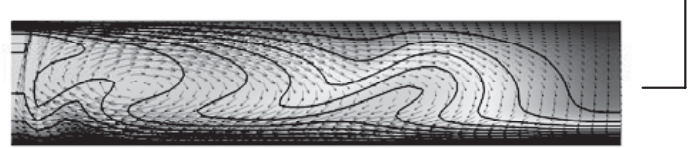

第 7 図 規則的振動磁気熱対流における 1 周期中の速度べクトルと等 温線の変化 $\left(P r=0.71, \gamma \cdot R a=5 \times 10^{6}, Z D=4.75\right)$

$\leq 1.017$, すなわち $\pm 2 \%$ 以内であり, 容器内の熱バランス はほぼ保たれていると考えられる。図中の破線は $N u=1$ を示すが, $N u$ 数がこの数值を上回れば磁気力によって磁気 熱対流が誘起されていることを示す。第 6 図より，伝熱面 の平均 $N u$ 数は $\gamma \cdot R a$ と容器設置位置に強く依存すること がわかった。平均 $N u$ 数は, $\left(\operatorname{gradB} B^{2}\right)_{Z}$ が最大となる $Z D$ $=4.25$ で最大值をとり, $\gamma \cdot R a=5 \times 10^{6}$ のとき $N u_{\text {ave }}=$ 4.144 (第 6 図左図の $\triangle$ ), 一方, $\gamma \cdot R a=5 \times 10^{5}$ のとき $N u_{\text {ave }}=2.152$ (第 6 図右図の $\triangle$ ）であった。

第 6 図左図中の 4 つの黒塗り記号の計算条件下では, 規 則的振動磁気熱対流が発生することを先に述べた。具体的 には, $Z D=4.75$ に容器を設置し, 計算条件が $\operatorname{Pr}=0.71$, そして $\mathbf{\Delta}: \gamma \cdot R a=5 \times 10^{6}, \bigcirc: \gamma \cdot R a=4 \times 10^{6}$, $\gamma \cdot R a=3 \times 10^{6}, \boldsymbol{\nabla}: \gamma \cdot R a=2 \times 10^{6}$ のとき規則的な周 期と振幅を持った振動磁気熱対流が発生した。なお，周期 と振幅は $\gamma \cdot R a$ の増加とともに大きくなった。第 7 図は, $\gamma \cdot R a=5 \times 10^{6}$ のときに発生した規則的振動磁気熱対流 における 1 周期中の速度べクトルと等温線の変化を示した ものである。なお，第 4 図と同様に図の右側が容器の中心, 左側が容器側壁, そして上端が加熱面, 下端が冷却面であ る。第 7 図 (a) の磁気熱対流パターンは, ほぼ第 4 図 (c) の $Z D=5$ に容器を設置したときに発生した定常磁気熱対 

流パターンとほぼ一致する。しかし， $Z D=4.75$ に容器を 設置した場合, 第 7 図 (a) の磁気熱対流は安定には存在で きず，第 7 図 (b) と (c) に示すように中心軸付近の高温流 体は側壁方向に徐々に移動する. その後, 第 7 図 (d) に示 すように第 4 図 $(\mathrm{d})$ の $Z D=4.25$ に容器を設置したとき に発生した定常磁気熱対流パターンとほぼ同様の磁気熱対 流パターンが形成される。しかしながら, この磁気熱対流 も安定には存在できず，第 7 図 (e) と (f) に示すように磁 気熱対流パターンは变形し続け, 再び第 7 図 (a) の磁気熱 対流パターンが形成される。このような複雑な渦構造の規 則的変化は, 無重力空間において課題となっている流体の 混合や攪拌を非接触で行うのに利用できるのではないかと 期待される。

\section{6. 結言}

本研究では, 磁気力によって誘起された非磁性磁気熱対 流の伝熱流動特性を体系的にまとめるための研究の一環と して，また磁気力の宇宙利用を模索するための基礎的研究 として, 無重力場における薄い加熱密閉円筒容器内に封入 された常磁性空気に対する磁気力の効果を数值解析によっ て詳細に調べた。

この結果, 無重力場で形成される熱伝導状態の静止空気 に磁気力を作用させると, 磁化率差によって磁気熱対流を 誘起できる可能性があることを示した，また，この磁気熱 対流の強さは容器と磁場中心との相対的な位置に強く依存 し, 定常磁気熱対流だけではなく振動磁気熱対流までも誘 起できることを示した。すなわち, 磁気力を利用すれば無 重力場においても熱対流を誘起することができ, 熱伝導の ときよりも伝熱面と接触する流体との間のエネルギー交換 を促進できることがわかった。

一方, 重力場で形成される密度成層空気に磁気力を作用 させると, 無重力場とほぼ同様の磁気熱対流を誘起できる 可能性があることを示した。これは, 超伝導磁石が発生す る強力な磁場空間を利用すれば, 地球上にいながら疑似無 重力空間の実験ができる可能性があることを示している.

\section{参 考 文 献}

1) Chandrasekhar, S.: Hydrodynamics and Hydromagnetic Stability, Dover Publ., New York, 1981.
2) Akamatsu, M., Higano, M. and Ozoe, H.: Elliptic Temperature Contours under a Transverse Magnetic Field Computed for a Czochralski Melt, Int. J. Heat Mass Transfer, 44 (2001), pp. 3253-3264.

3) Rosensweig, R. E.: Ferrohydrodynamics, Cambridge Univ. Press, London, 1985.

4) Yamaguchi, H., Kobori, I., Uehata, Y. and Shimada, K.: Natural Convection of Magnetic Fluid in a Rectangular Box, J. Magnetism Magnetic Mater., 201 (1999), pp. 264-267.

5) Braithwaite, D., Beaugnon, E. and Tournier, R.: Magnetically Controlled Convection in a Paramagnetic Fluid, Nature, 354 (1991), pp. 134-136.

6) Bai, B., Yabe, A., Qi, J. and Wakayama, N. I.: Quantitative Analysis of Air Convection Caused by Magnetic-Fluid Coupling, AIAA J., 37 (1999), pp. 1538-1543.

7) Wakayama, N. I.: Utilization of Magnetic Force in Space Experiments, Adv. Space Res., 24 (1999), pp. 1337-1340.

8) 若山信子: 勾配磁場下の気体の挙動と化学反応, 物質工学工業技 術研究所報告, 3 (1995), pp. 307-320.

9) 若山信子: 磁気力の新しい利用に関する研究, 物質工学工業技術 研究所報告, 6 (1998), pp. 219-233.

10) Kitazawa, K., Ikezoe, Y., Uetake, H. and Hirota, N.: Magnetic Field Effects on Water, Air and Powders, Physica B, 294-295 (2001), pp. 709-714.

11) Uetake, H., Hirota, N., Nakagawa, J., Ikezoe, Y. and Kitazawa, K.: Thermal Convection Control by Gradient Magnetic Field, J. Appl. Phys., 87 (2000), pp. 6310-6312.

12) Akamatsu, M., Higano, M. and Ogasawara, H.: Numerical Computation on Magnetothermal Air Jet in Gravitational and Non-Gravitational Fields, Ann. N. Y. Acad. Sci., 1077 (2006), pp. 613-628.

13) Akamatsu, M. and Higano, M.: Magnetothermal Wind Visualized by Numerical Computation, J. Visualization, 10 (2007), pp. 261-270.

14) Akamatsu, M., Higano, M., Takahashi, Y. and Ozoe, H.: Numerical Computation of Magnetothermal Convection of Water in a Vertical Cylindrical Enclosure, Int. J. Heat Fluid Flow, 26 (2005), pp. 622-634.

15) Akamatsu, M., Higano, M. and Ozoe, H.: Heat Transfer Control of Rayleigh-Benard Natural Convection of Air by Kelvin Force, Num. Heat Transfer, 51 (2007), pp. 159-177.

16）桜庭順二：冷凍機を用いた使いやすい超伝導マグネット，応用物 理, 65 (1996), pp. 412-413.

17) Tagawa, T., Shigemitsu, R. and Ozoe, H.: Magnetizing Force Modeled and Numerically Solved for Natural Convection of Air in a Cubic Enclosure: Effect of the Direction of the Magnetic Field, Int. J. Heat Mass Transfer, 45 (2002), pp. 267277.

18) 平野博之: 流れの数值計算と可視化, 丸善, 東京, 2004, pp. 129252.

19）日本熱物性学会編: 新編熱物性ハンドブック, 養賢堂, 東京, 2008, p. 67 . 